\title{
Весна Карин
}

\section{Плесна пракса Кордунаша у Војводини између традиције и сцене}

UDC 784 (497.5 Kordun)

Anстракт: Војводину, као Аутономну Покрајину Републике Србије, карактерише мултиетничност. Иако значајан део српске популације чине староседеоци, већина Србаје пореклом из крајева јужно од Саве и Дунава. Они су у току 20. века, долазили у војвођанске крајеве, било организованим пресељавањем (колонизацијом) или стихијним сеобама.

Циљ рада је да се покаже континуитет и промене плесне праксе српског становништва са Кордуна у новом географском локализованом контекстуалном оквиру-Војводини, односно у оквиру одређених прилика за плес попут фестивала, концерата, свадбе и сл.

Кључне речи: Кордунаши, Динарци, Војводина, плесна пракса, сцена.

Сложена етничка структура војвођанског становништва последица је познатих историјских збивања. После Другог светског рата извршена је велика колонизација када је Војводину населило на десетине хиљада домаћинстава из планинских и ратом опустошених крајева бивше Југославије. Највише их је дошло из Босне и Херцеговине и Хрватске.

Преласком српског становништва са Кордуна (Хрватска) на ново подручје, у Војводину, преносе се и веровања, обичаји, музичка и плесна традиција, уз велики труд да се на најбољи начин прилагоди новим условима живота. Исељавањем Срба са простора Кордуна, губи се један део историје и културе поменутог простора. С друге стране, Војводина постаје богатија за део те културе, будући да се традиционални плес више сачувао на новом подручју Војводине, него на Кордуну.

1 Рад је настао у оквиру пројекта Плесна пракса динарских Срба у Војводини који је реализован под покровитељством Покрајинског секретаријата за културу и јавно информисање АП Војводине и у оквиру пројекта Музичка и играчка традиција мултиетничке и мултикултуралне Србије (бр. 177024), који се реализује на Факултету музичке уметности под покровитељством Министарства за науку и технолошки развој Републике Србије. 
О игри и музици Динараца писано је у више наврата, али различит обим и врста грађе и текстова, као и неједнаки теоријско-аналитички приступи разматрања не успевају да понуде конзистентан концепт (модел) који омогућава да сложена слика плесова Динараца у оквиру специфичне геополитичке средине - Војводине, буде системски објашњена ${ }^{2}$. Плесови Динараца у Војводини више не опстају као некад у земљи матици тј. не преносе се на исти начин и немају исто значење. Они се групишу и посматрају у једној свеобухватној експликацији својих структуралних елемената у одређеним конситуацијама новог контекста, односно, обележавају се заједничким називом „плесна пракса““3. Временски оквир истраживања плесне праксе Динараца у Војводини представља период друге половине 20. и почетак 21. века.

Ради бољег разумевања текста који се ставља на увид читаоцу, под појмом Динарии подразумеваће се Срби из Црне Горе, Херцеговине, Босанске Крајине, Далматинске Загоре, Лике, Кордуна и Баније досељени у Војводину у 20. веку. Такође, треба нагласити да је поменути термин научно конструисан и садржи у себи заједнички имагинарни идентитет у односу на Србе староседеоце у Војводини, јер су на тај начин сви Срби из поменутих региона груписани у једну заједницу која дели сличне облике традиционалне културе, укључујући и плес.

Постоји мишљење да генерације предака данашњег војвођанског динарског становништва, које су рођене у новој средини, по много чему, а посебно по неговању традиционалних обичаја, песама и игара, сведоче колико је снажна традиционална

2 Поједине публикације воде се као веома значајне и валидне (као нпр. Народне игре Србије - грађа), иако нису увек резултат пажљивих и детаљних етнокореолошких и етномузиколошких истраживања.

3 Ослањајући се, с једне стране, на општу, марксистичку, Бурдијеову и Шуваковићеву дефиницију термина „пракса“, и, с друге стране, на термин „плес“ дефинисан као целовит феномен у којем су у нераскидивом синкретичком јединству обједињени звук и покрет, у раду „Одређење синтагме 'плесна пракса' у етнокореолошком дискурсу. Случај плесне праксе Динараца у Војводини“ (рад у припреми за штампу) разматране су могућности концептуализације поменуте синтагме. Плесну праксу сам одредила као: процесуални облик стваралачке делатности иманентне човеку, у којем плес није постављен као природно по себи разумљиво, већ који је заснован на експликацији својих структуралних елемената у одређеном контексту и кроз своју повезаност са другим друштвеним праксама добија нови ниво вредности који је део културе, друштва, а потенцијално и уметности.

4 Сања Ранковић је у докторској дисертацији дефинисала оквир у којем ће се употребљавати појам Динарии у односу на досадашња научна разматрања и навела да ће овај појам бити коришћен „да у географском и културном смислу означи српско становништво из планинских - динарских предела Хрватске, Босне, Херцеговине и Црне Горе које је у више наврата, а посебно током XX века, населило Војводину“ (Ранковић, 2012:16). Иако је поменути појам добро дефинисан, не бих се сложила само у једном. Наиме, иако се сво становништво назива Динарцима, не припадају сви „планинским - динарским пределима“ наведених региона. Стога, иако остварен на темељу парадигме једног географско-културног простора (Динарске планине), предлажем да се ипак посебно наведу региони одакле потичу Динарци у Војводини. 
пракса њиховог завичаја. Друга хипотеза указује на чињеницу да плесна и музичка традиција Срба из Босне и Херцеговине и Хрватске колонизованих у Војводини живи својим новим животом.

Игра и музика чине недељив феномен људског изражавања које обједињујемо под једним именом - плес. Базично полазиште у концептуализацији предмета истраживања у раду представља студија СеленеРакочевић Игре плесних структура - традииионална игра и музика за игру Срба у Банату у светлу узајамних утииаја (Rakočević, 2011) која сагледава играчке и музичке елементе и њихов узајамни утицај у стварању и обликовању традиционалних плесова Срба у Банату у току 20. века. Појам традиционалног плеса је у овој студији концептуализован и третиран као целовит феномен, који подразумева и играчку и музичку компоненту извођења. Ауторка свесно користи термине игра и музика, јер они, према њеном мишљењу, у непосредном извођачком процесу сачињавају нераскидиву синкретичку везу. Иако Динарци користе термин игра, појам плес ће у овом раду обједињавати игру и музику за игру.

Истраживања су спорадично спровођена у периоду од 2001. године, настављена и наредних година. У периоду докторских студија (од 2008. године), избором теме дисертације под називом Плесна пракса Динараца у Војводини, истраживања су интензивирана и проширена на целу Војводину и трају све до данас, а вероватно ће бити настављена и у будућности. За потребе овог истраживачког рада, неизмерно су ми помогли видео и аудио снимци које су ми уступили професори и колеге, као и казивачи уступајући ми снимке свадби и разних весеља 5 . Примарни циљ поменутих теренских истраживања био је сакупљање и бележење плесова Динараца широм Покрајине и дефинисање оних који чине окосницу „динарског“ плесног репертоара у новом контексту - Војводини.

Извођење плесова одвија се у новом контексту, у новим ситуацијама. То је довело до новог питања: „Зашто Динарци у Војводини играју?“ и отворило ново поглавље које се тиче испољавања различитих идентитета кроз плес (као нпр. етнички или супкултурни идентитет).

Кордунаши у Војводини играју у различитим приликама. Израз „прилика за игру“ у етнокореологији у Србији прве користе Даница и Љубица Јанковић, који, потом, прихватају Оливера Младеновић, Милица Илијин, Оливера Васић, као и Селена Ракочевић, али га различито дефинишу и користе. Према речима Селене Ракочевић, поменути појам је употребљаван у „његовом непосредном говорном значењу, које је подразумевало само један контекстуални сегмент извођења традиционалних игара - време, сагледавано кроз годишњи и животни циклус обредно-обичајних радњи“, затим „у сврху набрајања појединачних 'играчких догађаја' који су практиковани у оквиру појединих локалних

5 Овом приликом им се свима топло захваљујем. 
плесних пракси током године дана или поводом значајних тренутака у животу појединца“" (Ракочевић, 2009: 21). У мањој мери прилика за игру коришћен је и у смислу просторног лоцирања извођења традиционалих игара - „места за игру“ (Ракочевић, 2009: 23). У односу на уобичајено значење термина „прилике за игру“ у етнокореологији у Србији које се најчешће поистовећује само са временом извођења традиционалних игара, Селена Ракочевић модификује израз „прилике за игру“ у термин „прилике за плес“ који обухвата и време, и место, и репертоар и који реферира на шири друштвени контекст извођења традиционалних плесова, а што омогућава потпунију идентификацију начина кодирања културног система чији су конститутивни део (Ракочевић, 2009: 25) ${ }^{6}$.

У савременој етнокореологији контекст извођења традиционалних игара именован је термином „играчки догађај“. Он је, такође, различито дефинисан и концептуализован; као комплекс искуства (Snyder, 1989: 2), као друштвена прилика која се издаваја из свакодневног живота, уоквирена у одређеном времену и простору када се људи окупљају са посебним разлогом (Ronström, 1989: 23), као основно средство за социјалну размену између рода, генерација и друштвених класа (Ivancich Dunin, 1989: 30), као догађај у којем је симболичка играчка активност неопходна (Giurchescu, 1989: 34), као мултиструктурни догађај (Staro, 1989: 81), или као уникатна, јединствена и креативна активност (Zhivkov, Shutarbanova, 1989: 110,112) и томе сл. Без обзира на ова различита тумачења, односно различите аспекте из којих су етнокореолози и антрополози посматрали плес, оно што је заједничко за сам концепт „играчки догађај“, а који је инаугурисан 1988. године у оквиру научног скупа Етнокореолошке секције Интернационалног савета за традиционалну музику (ICTM) у Копенхагену, јесте да је то сасвим конкретна плесна ситуација. То усредсређење на „играчки догађај“ настаје управо због тога да би се у етнокореологији направио заокрет од реконструкције некадашње плесне праксе на основу сећања казивача на сасвим конкретне активности.

Дакле, етнокореолози у Србији служе се највише термином „прилике за игру/ плес“ који, сложићу се са Селеном Ракочевић, на српском језику има обухватније значење од термина „играчки догађај“ и подразумева све могућности реализације потениијалних (курзиви С. Ракочевић) играчких догађаја (Ракочевић, 2009: 25), док термин „играчки догађај“ у америчкој антропологији и етнокореологији функционише у домену реализације конситуација, односно манифестација плеса у непосредним датим околностима који могу да одступају од утврћеног традиционалног поретка (Ракочевић, 2009: 25-26).

На основу свега наведеног, може бити закључено да плесови у оквиру обреднообичајна пракса Кордунаша у Војводини не постоји, већ постоје ситуације у којима је присутан плес, и такве ситуације могу бити назване „играчки

6 Више о термину „прилике за игру“ у: Ракочевић, 2009: 21-29. 
догађај“"7. Фестивали, свадбе, дружења и весеља јесу прилике за плес које се могу, али и не морају реализовати. Ако их има, оне постају сасвим конкретни играчки догађаји, односно конситуације. Дакле, плесови Кордунаша у Војводини реализују се искључиво у оквиру појединачних играчких догађаја, односно плесова посматраних у партикуларном контексту, односно у конситуацијама ${ }^{8}$. Под поменутом теоријском конструкцијом подразумева се конкретна ситуација, место и време извођења плеса ${ }^{9}$. Кад је у питању плесна пракса Кордунаша у Војводини, она се манифестује у неколико конситуација: појединачне концертне активности у оквиру фестивала, разни концерти, свадбе и разна дружења и весеља.

Међу многим фестивалима за Кордунаше, као уосталом за све Динарце, у Војводини један од најзначајнијих јесте Фестивал Намем роду и потомству. Фестивал Нашем роду и потомству је комплексна и специфична форма који се одржава једном годишње у Бачкој Тополи (покренут је 1993. године) и окупља Србе из Црне Горе, Босне и Херцеговине и Хрватске који данас живе у Војводини ${ }^{10}$. Циљ Фестивала је да покрене и афирмише друштва која негују духовно и материјално стваралаштво Срба досељеника, обједињујући динарске, али и спецификујући регионално-локалне одлике традиционалне културе.

Унутрашња сегментираност концерта, као друге прилике за плес, у оквиру које се срећу традиционални плесови, сценски реконструисани, показује да се Кордунаши представљају као равноправни учесници јавно овереног репрезента. Иако најчешће изводе плесове одакле потичу, извођење плесова у оваквој конситуацији нема за циљ да се искажу локално-регионални идентитети, већ да се публици представе плесови различитих делова Србије, као и бивше СФРЈ, будући да се на сцени представља велики број учесника из различитих КУД-ова, односно градова.

Срби са Кордуна који данас живе у Војводини и даље играју у појединим приликама као што су свадбе и друга већа окупљања, али тада поред појединих

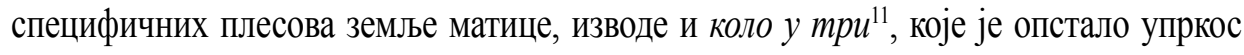

7 Ово потврђују и речи Јелене Поповић која у дипломском раду Вокална традиција Кордунаша из Кљајићева у оквиру годишњег ииклуса наводи да „ниједна фолклорна категорија произашла из живота и стваралаштва у Завичају, није више део свакодневног живота у новом Крају“ (Поповић, 2011: 2).

8 Контекстуална ситуација, односно конситуација је термин који користе руски лингвисти, етнолози и етномузиколози, а који је у српску етномузикологију увела Мирјана Закић 2006. године. Више о томе: Закић, 2009: 235.

9 Оригинална дефиниција гласи да је конситуација „конкретна ситуација, место и време извођења музичког текста“" (Закић, 2008:219), међутим с обзиром на то да се у раду бавим етнокореолошким и етномузиколошким научним истраживањем, синтагму „музички текст“ замењен је изразом „плес“.

10 Аналитичко сагледавање Фестивала Нашем роду и потомству објављено је 2012. године у раду „Фестивал 'Нашем роду и потомству': репрезент духовног и материјалног стваралаштва динарских Срба колонизованих у Војводини“. Више о томе: Карин, 2012: 508-520.

11 У етнокореологији у Србији овај тип плеса познат је под термином коло у три, који је осмислила Оливера Васић. То је репрезент групе плесова који имају различита имена и мелодије, а који 
процесу модернизације. Иако себе детерминишу као Кордунаши, када играју у оквиру свадбе или неког другог весеља, они играју коло у три, односно ужичко коло.

Када се посматрају прилике за плес, тј. конситуације, може се запазити да се у прве две плес изводи на сцени, док у друге две не. Али, ако посматрамо извођење самог плеса, да ли можемо да кажемо да је оно у оквиру свадбеног весеља или неког другог славља такође на неки начин сценско?

„Ceo svet nije, naravno, pozornica, ali je teško odrediti trenutke kada to nije" - Irvin Gofman (Šekner, 1992: 215)

Према речима Ричарда Шекнера (Richard Schechner), теоретичара театра, „, teoriji ne postoji nijedan primer scenskog izvođenja koji se odigrava svuda i pod svim okolnostima. Niti je jednostavno odrediti granicu šta je ili šta se ne može podrazumevati pod scenskim izvođenjem“ (Šekner, 1992: 209). Будући да је свет сценског извођења веома различит и распрострањен, Шекнер у есеју „Raspon scenskog izvođenja“ покушава да, уз помоћ психологије, неурологије и биологије, укаже на то колика је магнитуда сценског извођења. Табеларним приказом, Шекнер показује њихову велику разноврсност, и у оквиру жанра, и у оквиру употребе времена и простора (без обзира на културу или жанр), односно међусобну повезаност догађајавремена-простора (Šekner, 1992: 213). За то му служе следећи критеријуми: „1) događaji koji se nazivaju predstavama u ovoj ili onoj kulturi; 2) događaji koje naučnici tretiraju 'kao predstave'“ (Šekner, 1992: 209). На тај начин аутор даје примере представа различите магнитуде, различитих начина организовања времена, простора и догађаја и поставља питања: „Kada je predstava predstava? (...) Kada su delići ponašanja preuzeti iz jednog konteksta i predstavljeni u drugom, da li će biti neke razlike ako, u ponovljenom predstavljanju, deo ponašanja bude označavao nešto potpuno različito od onoga što je označavao 'prvobitno'? (Šekner, 1992: 241).

На крају свог рада, Шекнер закључује да се тзв. сценичност - или, уобичајено „представа“ - налази свуда у животу, од обичних гестова до макродрама, али да разлике у нивоима, како он каже, „распона представа“ свакако воде према разликама у врсти. Аутор то појашњава на следећи начин: „Estetski žanrovi - pozorište, ples, muzika - stavljeni su u okvir pozorišta, emitujući namere svojih stvaralaca njihovoj publici. Drugi žanrovi nisu tako često jasno obeleženi - ali ih ovo ne čini manje sceničnim“ (Šekner, 1992: 243).

је базиран на истом кореолошком обрасцу (један такт у десну страну, три такта у месту - један такт у леву страну, три такта у месту), „који подразумева симетричну осмотактну структуру основног обрасца корака, са дихотомном унутрашњом организацијом четворотактних фраза и изводи се у формацији кола (најчешће отвореног)“ (Ранисављевић, 2012: 557). 
Будући да Шекнер сматра да је свако извођење мање или више сценско, неопходно је да у раду буде јасније разграничено шта се подразумева под термином сценско, а шта под термином не-сценско извођење. За то би могле да послуже детерминанте антрополога Мирославе Лукић-Крстановић: када се плес изводи на сцени (у оквиру Фестивала Нашем роду и потомству и других фестивала или јавних наступа, тј. концерата) онда је он ,јавно оверен репрезент“, дакле сценско извођење, док се у супротном он испољава „кроз ритуалну дистрибуцију у приватној сфери деловања“ (свадба, славља и сл.) (Лукић-Крстановић, 2010: 140).

Анализа је показала да када је плес извођен на сцени, он постаје „естетски жанр“, учесници припадају одређеним КУД-овима или изворним групама и тада постоји јасна подела на извођаче и публику и тада најчешће путем плеса изражавају свој супкултурни идентитет. Када се плес испољава кроз ритуализовану дистрибуцију у приватној сфери деловања онда плесове могу изводити сви који присуствују одређеном догађају и тада не постоји јасна диференцираност публике и извођача. Исто тако, извођење плесова у таквим приликама немају за циљ да се искажу динарски локално-регионални идентитети, већ играју ужичко коло и тиме показују српски национални идентитет ${ }^{12}$. То можемо рећи јер данас тај тип плеса „репрезентује модел српског националног идентитета изражен кроз плес“ (Ranisavljević, 2011:95). Наравно, поред испољавања националног идентитета, извођење кола у три има такође социјалну и забавну функцију (Ранисављевић, 2012: 567).

Када се анализира плесна пракса Кордунаша у Војводини, може се запазити да је дошло до дисконтинуитета у преношењу и неговању музичког и играчког језика и да је њихова културна баштина из претходног контекста (регион одакле су се преселили - Кордун) пренесена на сцену. У приложеној табели, плесови су класификовани према фреквентности извођења и јасно се види које плесове Кордунаши у Војводини и даље изводе, а које не.

На основу свега наведеног, изражавање српског националног идентитета кроз плес је, сложићу се са Оливером Васић, интегрални део ширег процеса редефинисања истог (Ранисављевић, 2012: 563 арид Васић, 2011: 4). Поред тога, Динарци у Војводини желе да изразе свој локално-регионални идентитет, али то чине на сцени. Сценичне активности, како их Шекнер одређује, практиковане на овај начин, дакле кроз фестивале и концерте, с једне стране, и свадбе и друге врсте весеља са друге, јесу део друштвених догађаја који „,sс̌іnjavaju platformu za izgradnju 'grupnog kulturnog identiteta'“(Petrov, 2011: 183).

$12 \mathrm{y}$ једном интервјуу са казивачем из Кљајићева на питање зашто свира ужичко коло уместо неке мелодије из свог краја (Кордуна), казивач је одговорио да тако људи желе. 


\begin{tabular}{|c|c|c|c|}
\hline $\begin{array}{l}\text { Редни } \\
\text { број }\end{array}$ & Назив плеса & $\begin{array}{l}\text { Плесови по сећағу } \\
\text { и из доступне } \\
\text { литературе }\end{array}$ & $\begin{array}{c}\text { Плесна пракса } \\
\text { (извођење плесова у } \\
\text { садашье време) }\end{array}$ \\
\hline 1. & Ужичко коло & + & +++ \\
\hline 2. & $\begin{array}{c}\text { Милица је вечерала и на } \\
\text { сокак истрчала }\end{array}$ & + & +++ \\
\hline 3. & \begin{tabular}{|c|} 
Опа, цупа, скочи \\
(Крушке, јабуке, \\
шљиве)
\end{tabular} & + & +++ \\
\hline 4. & Дрмеш & + & +++ \\
\hline 5. & Бећарац & + & ++ \\
\hline 6. & $\begin{array}{c}\text { Ајд на лево, брате } \\
\text { Стево }\end{array}$ & + & ++ \\
\hline 7. & Повратно коло & + & ++ \\
\hline 8. & Ај по два & + & ++ \\
\hline 9. & Ај по четири & + & ++ \\
\hline 10 & Укрштено & + & ++ \\
\hline 11. & Разви (Зави) коло & + & ++ \\
\hline 12. & Кукуњешће & + & ++ \\
\hline 13. & Дуње ранке & + & ++ \\
\hline 14. & Цурско коло & + & ++ \\
\hline 15. & Преваранта & + & ++ \\
\hline 16. & $\begin{array}{c}\text { Испред куће плава } \\
\text { ружа пала }\end{array}$ & + & ++ \\
\hline 17. & $\begin{array}{c}\text { Сељанчице малена ко } \\
\text { ти кућу чува }\end{array}$ & + & ++ \\
\hline 18. & Секо Јело & + & + \\
\hline 19. & О, мој Миле, медени & + & + \\
\hline 20. & Пауна & + & + \\
\hline 21. & Извор вода извирала & + & + \\
\hline 22. & Сремица & + & \\
\hline 23. & Шестица & + & \\
\hline 24. & Мађарац & + & \\
\hline 25. & $\begin{array}{c}\text { Марамица од бијеле } \\
\text { свиле }\end{array}$ & + & \\
\hline 26. & Девојачко коло & + & \\
\hline 27. & $\begin{array}{l}\text { Ја у колу рубац ми } \\
\text { се вије }\end{array}$ & + & \\
\hline 28. & $\begin{array}{c}\text { Ова мала што игра } \\
\text { на лево }\end{array}$ & + & \\
\hline 29. & $\begin{array}{c}\text { Коло игра коловође } \\
\text { нема }\end{array}$ & + & \\
\hline 30. & Перино коло & + & \\
\hline 31. & Ej, мати, мати, мати & + & \\
\hline 32. & Врањанка & + & \\
\hline 33. & Дошло писмо из Босне & + & \\
\hline
\end{tabular}

Табела 1. Репертоар Кордунаша некад и сад 


\section{Лuтература:}

Васић, Оливера (2011). Коло - природна етапа у развоју народне игре, или истицање националне припадности. Рукопис.

Giurchescu, Anca (1989). „A Qusetion of Method: Contextual Analysis of Dancing at the Vlachs 'Hora' in Denmark. "U: The Dance Event: a Complex Cultural Phenomenon (15th Simposium of the ICTM Study Group on Ethnochoreology, 1988). Ur. Lizbet Torp. Copenhagen: ICTM Study Group on Ethnochoreology, 34-43.

Dunin, Elsie (1989). „Dance Events as a Means to Social Interchange.“ U: The Dance Event: a Complex Cultural Phenomenon (15th Simposium of the ICTM Study Group on Ethnochoreology, 1988). Ur. Lizbet Torp. Copenhagen: ICTM Study Group on Ethnochoreology, 30-33.

Закић, Мирјана (2008). „Контекст - конситуација - текст“. У: Дани Владе С. Милошевића (зборник радова са међународног научног скупа, 10-11. април 2008. године). Ур. др Димитрије О. Големовић. Бања Лука: Академија умјетности и Музиколошко друштво Републике Српске, 215-227.

Закић, Мирјана (2009). Обредне песме зимског полугођа. Системи звучних знакова утрадииијијугоситочне Србије. Етномузиколошке студије-дисертације. Београд: Факултет музичке уметности.

Zhivkov, Torod, Shturbanova, Anna (1989). „Dance Event: Complex Cultural Phenomenon."U: The Dance Event: a Complex Cultural Phenomenon (15th Simposium of the ICTM Study Group on Ethnochoreology, 1988). Ur. Lizbet Torp. Copenhagen: ICTM Study Group on Ethnochoreology, 110-114.

Карин, Весна (2012). „Фестивал 'Нашем роду и потомству': репрезент духовног и материјалног стваралаштва динарских Срба колонизованих у Војводини“. У Владо С. Милошевић - етномузиколог, композитор и педагог. Традииија као инспирација (зборник са научног скупа), ур. др Соња Маринковић и мр Санда Додик. Бања Лука: Академија умјетности Универзитета у Бањој Луци и Музиколошко друштво Републике Србије, 508-520.

Лукић-Крстановић, Мирослава (2010). Спектакли ХХ века. Музика и моћ. Београд: Етнографски институт САНУ.

Petrov, Ana (2011).,,Koncert kao građanska institucija“. U: Sociologija, časopis za sociologiju, socijalnu psihologiju i socijalnu antropologiju, vol. 53, br. 2. Ur. Jovo Bakić. Beograd: Sociološko udruženje Srbije i Crne Gore i Institut za sociološka istraživanja Filozofskog fakulteta u Beogradu, 177-194.

Поповић, Јелена (2011). Вокална традиија Кордунаша из Кљајићева у оквиру годишъег ииклуса (дипломски рад, рукопис). Ментор: др Нице Фрациле, ред. проф. Нови Сад: Академија уметности Нови Сад.

Ранисављевић, Здравко (2012). „Симболичко значење жанра коло у три у плесној 
пракси Срба.“ У: Владо С. Милошевић - етномузиколог, композитор и педагог. Традищија као инспиращија. (зборник са научног скупа). Ур. др Соња Маринковић и мр Санда Додик. Бања Лука: Академија умјетности Универзитета у Бањој Луци и Музиколошко друштво Републике Србије, 557-570.

Ранковић, Сања (2012). Вокални дијалекти динарских Срба у Војводини (докторска дисертација, рукопис). Ментор: др Мирјана Закић, доцент. Београд: Факултет музичке уметности.

Ракочевић, Селена (2009). Традиционална игра и музика за игру Срба у Банату у светлу узајамних утицаја (докторска дисертација, рукопис). Ментори: проф. др Димитрије О. Големовић и проф. др Оливера Васић. Београд: Факултет музичке уметности.

Rakočević, Selena (2011). Igre plesnih struktura - Tradicionalna igra i muzika za igru Srba u Banatu u svetlu uzajamnih uticaja. Etnomuzikološke studije - disertacije. Београд: Факултет музичке уметности.

Ronström, Owe (1989). „The Dance Event: a Terminological and Methodological Discussion of the Concept." U: The Dance Event: a Complex Cultural Phenomenon (15th Simposium of the ICTM Study Group on Ethnochoreology, 1988). Ur. Lizbet Torp. Copenhagen: ICTM Study Group on Ethnochoreology, 21-29.

Snyder, Allegra (1989). „Levels of Event Patterns: a Theoretical Model Applied to the Yaqui Easter Ceremonies." U: The Dance Event: a Complex Cultural Phenomenon (15th Simposium of the ICTM Study Group on Ethnochoreology, 1988). Ur. Lizbet Torp. Copenhagen: ICTM Study Group on Ethnochoreology, 1-20.

Staro, Placida (1989). „Widespread Models for the Analysis od Folk Dance.“ U: The Dance Event: a Complex Cultural Phenomenon (15th Simposium of the ICTM Study Group on Ethnochoreology, 1988). Ur. Lizbet Torp. Copenhagen: ICTM Study Group on Ethnochoreology, 81-92.

Šekner, Ričard (1992). Ka postmodernom pozorištu (Između antropologije i pozorišta). Priredile i prevele: Aleksandra Jovićević i Ivana Vujić. Beograd: Fakultet dramskih umetnosti i Institut za pozorište, film, radio i televiziju. 


\section{Dance practice of the Kordun people in Vojvodina between tradition and stage ${ }^{13}$}

Abstract. Vojvodina, as the Autonomous Province of the Republic of Serbia, is characterised by multiethnicity. Although a significant part of the Serbian population is made of indigenous inhabitants, most of the Serbs originate from the regions south of the rivers Sava and Danube. They came to Vojvodina during the $20^{\text {th }}$ century, either in organised migrations (colonisation) or in spontaneous migrations.

The aim of the paper is to point to the continuity and changes in traditional dance practice of the Serbian population from Kordun in the new geographical localised contextual environment - Vojvidina, that is to say at certain occasions for dancing such as festivals, concerts, weddings etc.

Key words: Kordun people, Dinara people, Vojvodina, dance practice, stage

13 The paper has been written as part of the project Dance practice of the Serbs from the Dinara in Vojvodina which has been realized under the patronage of the Provincial Secretariat for Culture and Public Information of the Autonomous Province of Vojvodina, within the project Musical and Dance Tradition of Multiethnical and Multicultural Serbia (No. 177024), which is realized at the Faculty of Music Art under the patronage of the Ministry of Science and Technological Development of the Republic of Serbia. 